\title{
The Construction of Early Career Teachers' Identities: Coping or Managing?
}

\author{
Ji Hong ${ }^{1}$, Christopher Day ${ }^{2}, \&$ Barbara Greene ${ }^{1}$ \\ University of Oklahoma, USA ${ }^{1}$ \\ University of Nottingham, $\mathrm{UK}^{2}$
}

\begin{abstract}
This paper examines how early career teachers cope with or manage the challenges that they experience during the transition from pre-service to the first and then the second year of teaching as they seek to establish stable, positive, professional identities and teach effectively in various school and policy contexts. Findings from three waves of interviews conducted with six elementary and secondary school teachers showed that, for these teachers in the early years of teaching, the construction of positive or negative, stable or unstable professional identities (Day, Kington, Stobart, and Sammons, 2006) was closely related to whether they coped with or managed various tensions and to their perceived effectiveness. The findings also revealed that their ability to cope or manage was not only influenced by the relative strength of commitment with which they entered teaching, but also by the kinds of school-level support which they experienced.

Keywords: Teacher Identity Construction; Emotions; Coping and Managing Challenges; Transitions
\end{abstract}




\section{Introduction}

Schools need to be staffed by teachers who are able to bring their best intellectual and emotional commitments to their work if they are to serve their students well. Always being willing and able to bring their "best selves" to teaching (Craig, 2013) is an on-going process that requires teachers to manage successfully both anticipated and unanticipated personal, school, and policy changes over time. For early career teachers especially, a key part in the process of becoming an effective teacher entails navigating challenging and uncertain classroom, professional role, school and policy landscapes. How they 'cope' with or 'manage' these will influence whether they are able to construct stable-positive or unstablenegative professional identities and become effective. The construction of teachers' identities is influenced by the ways in which they are able to manage successfully the emotional and intellectually complex interplay between distal (policy) and proximal contexts such as school culture, collegiality, and the quality of school leadership (Beauchamp and Thomas, 2009;

Day, Sammons, Stobart, Kington, and Gu, 2007). Yet in today's challenging school contexts and increasing accountability demands, the quality of teachers' effectiveness has been implicitly and explicitly equated with measurable performance outcomes, while devaluing emotional, relational, and moral aspects of teaching (Buchanan, 2015; Mockler, 2011; Stillman and Anderson, 2015; Stone-Johnson, 2014).

Early career teachers' experiences in school are likely to challenge and perhaps change their initial motivations, short and longer-term commitments, and professional identities. Yet there are relatively few existing studies that portray the contextualized experiences of pre-service and early career teachers. For example, although a group of researchers (e.g., Jugovic, Marusic, Ivanec, and Vidovic, 2012; Thomson and Palermo, 2014; 
Thomson, Turner, and Nietfeld, 2012) investigated pre-service teachers' teaching quality and preparedness in relation to their motivational typologies, professional goals, values, and levels of commitment, their work did not examine how those typologies and orientations are managed during the transitions which teachers in their early years experience as they move from being a student into their first years of teaching. There are also studies that have focused on the early years of teaching experiences in relation to the "reality shock", that many new teachers experience in moving from university based experiences where they are predominantly learners to schools where they are predominantly promoting learning among students (e.g., Fantilli and McDougall, 2009; Farrell, 2003).

Most of these studies have either tended to aggregate rather than nuance the first few years of experiences, or only focused on the first year experiences, as if the construction of professional identities is complete at that point, when it is clearly unlikely to be the case. Arguably, it is the influences during these years that may determine their longer term professional identities and effectiveness. As early career teachers continue to establish their professional identities, they are likely to engage in coping and managing a series of different classroom and staffroom experiences and events, many of which will be new to them. It is important, therefore, to investigate associations between 'coping' (to survive) and 'managing' (to flourish), the different ways that these influence teachers' professional identity development and perceived effectiveness, if we are to understand why some teachers stay and thrive and why others leave (Cooper and Alvarado, 2006; Ingersoll, 2001; Johnson andand Birkland, 2003; Lindqvist, Nordänger, and Carlsson, 2014).

\section{Construction and Transition of Early Career Teachers' Identities}


Professional identities are recognized as being closely interwoven with teachers' motivations to teach and their willingness and ability to sustain commitment (Day, Stobart, Sammons, and Kington, 2006a; Hong, 2010; Van den Berg, 2002). Unlike earlier research on identity which conceptualises it as singular, fixed and immutable (e.g., Cooley, 1902), our inquiry, along with many other current research (e.g., Alsup, 2006; Danielewicz, 2001; Rodgers and Scott, 2008), reflects post-modern characterisations in which professional identity is conceptualised as an on-going, dynamic process of construction. From this perspective, although shaped by prior experiences and beliefs, professional identities in the early years of teaching are provisional and likely to be challenged and changed as teachers are exposed to the tensions that are an inherent part of changing classroom dynamics, school environments, and policy demands (Cooper and Olson, 1996; Kelchtermans, 1993; Watson, 2006). How teachers' professional identities are shaped and whether they are positive or negative, stable or unstable is likely to depend upon how well they are able to cope with or manage the intellectual and emotional influences of personal, policy, school, and classroom environments (Day and Hong, 2016; Johnson and Birkland, 2003). Early career teachers' identity construction and transition are likely to be influenced by both proximal and distal contexts such as classroom and school environments and accountability policies.

There are several studies that have attempted to understand the developing nature of identity through the concepts of "tensions in learning to teach" (Smagorinsky, Cook, Moore, Jackson, and Fry, 2004), "identity dissonance” (Warin, Maddock, Pell, and Hargreaves, 2006), "identity shifts in the boundary space" (Beauchamp and Thomas, 2011), and "professional identity tensions" (Pillen, Den Brok, and Beijaard, 2013). The major focus of these studies is to understand the "what" of tensions in relation to different expectations, 
roles, beliefs, and connections between pre-service experiences and in-service experiences (Day, Stobart, Sammons, and Kington, 2006b; Olsen, 2008; Rodgers and Scott, 2008). Whilst they provide insights into the problems encountered in professional identity formation, they do not address the important question of "how" early career teachers cope with or manage these tensions over the longer-term in relation to various school and policy contexts and what are the effects on their perceived effectiveness. For teacher educators, it is particularly important to ensure that expectations, aspirations, and understandings of what is needed to be an early career teacher in contexts of change and challenge are surfaced and understood.

The current study was designed to investigate not only "what" the tensions between pre-service education and first year teaching are, but also "how" beginning teachers respond to the tensions, especially how the way they respond impacts on their identity positively or negatively, and their perceived capacity to teach to their best in the second and subsequent years of teaching. In the next section, we discuss how teachers respond to various tensions by "coping" or "managing" in their journey to establish positive and stable teacher identities.

\section{Coping or Managing Challenges}

Various challenges teachers experience may exist not only in the form of occasional or unanticipated events, but also in their on-going daily working conditions which may change over time. The way teachers respond to these challenges, the extent to which they are able to build and sustain their 'decisional capital' (Hargreaves and Fullan, 2012) and professional commitment may vary - some may "cope" with whilst others "manage". Decisional capital involves capacities and competencies to make sound decisions that can benefit students and their learning despite uncertainty and complexity of the situations. It is 
not something teachers can instantly acquire by reading textbooks or following certain instructions; rather decisional capital is accumulated and cultivated by experiencing both anticipated and unanticipated challenges, building rationale and intuitive repertoire of strategies, and practicing individual and collective reflections. Given this nature of decisional capital, early career teachers' responses to challenges may vary from coping to managing.

Earlier research on coping focused on personality or individual's trait as the major source of strengths or weaknesses due to the association between each form of psychopathology with a particular defensive style (e.g., Rapaport, Gill, and Schafer, 1945; Shafer, 1954). However, this approach was challenged by the transactional view of coping, which understands coping as a process where individuals appraise the external situation and his or her own internal resources, and make cognitive and behavioural efforts to handle the challenges. These efforts are dynamic and change depending on the adaptational context (Lazarus, 1993; Lazarus and Folkman, 1984). Aligned with this view, we understand that teachers' willingness, ability, and capacity to handle uncertainties and challenges are not static or fixed; rather they vary and fluctuate in relation to the nature of challenges, internal resources (e.g., self-efficacy, motivation, and sense of vocation) and external circumstances (e.g., support from colleagues and/or administrators and material resources).

Thus, simply restoring the balance between the demands (stressors and strains) and capabilities (resources and coping strategies) as a survival guide is not what we aim for. In order for teachers to teach to their best, they need to flourish and thrive by actively and proactively manage the challenges, thus overcoming them and moving forward. Then, the experiences of tension and disequilibrium are more likely to become a source for their learning and growth. Given this, we distinguish coping vs. managing as follows: 
Coping may be seen as enabling them to survive in the shorter or longer term without resolving the challenges. It is a passive and reactive response associated with weak sense of agency and decreasing confidence. When teachers lose their power to act, influence their own work, and make effective decisions, their weak sense of agency, which is often coupled with low confidence, is likely to impact negatively on their professional learning and hinders them from actively participating to resolve the challenges (Eteläpelto, Vähäsantanen, and Hökkä, 2015; Vähäsantanen, 2015). Thus, teachers who cope with challenges try to tolerate the intensity and complexity of demands and expectations. However, in coping, their cognitive, motivational, and emotional energy, which is drawn from the combinations of individual (e.g., sense of vocation, identity, and well-being) and social resources (e.g., colleagues and school leaders' support), is likely to be depleted and, if the spiral of depletion continues, they are less likely to be able to actively engage in overcoming and managing the challenging situation successfully.

Managing may be seen as overcoming or resolving the challenges, turning them to advantage in their teaching and building a positive sense of efficacy, agency, and professional identity. In actively responding to the various issues they face, teachers will, by definition, build their capacities to improve their practices over the longer term. With a stronger sense of agency and efficacy, they will be able to set new goals to resolve the challenges, identify proper strategies and resources, and take necessary actions within a clearly understood set of educational values and meaning. This process involves re-assessing their ideals, goals, and strategies, which are the core components that make up their professional identity. Also, their strong sense of efficacy, which is the beliefs about their "capabilities to exercise control over their own functioning and over events that affect their 
lives" (Bandura, 1994, 71), positively contribute to this process by providing a sense of certainty anchored in their sense of self despite uncertain and challenging situations. Thus, managing challenges through the active exercise of their agency and strong sense of efficacy, will contribute to the development of a positive, stable sense of professional identity (Buchanan, 2015; Ruohotie-Lyhty and Moate, 2016).

\section{Research Questions}

The study investigated the experiences of teachers in their early career that challenge their understandings of what teaching to their best means; the extent to which they "cope" (to survive) or "manage" (successfully overcoming challenges); how these impact on their professional identity formation and perceived effectiveness; and the implications for universities and schools. Six pre-service elementary and secondary teachers were followed over three years during the transitions from pre-service to the first year, and then second year of teaching. We addressed the following research questions:

- What tensions do beginning teachers experience in the first two years of teaching?

- How do they cope with or manage the tensions in relation to their inner landscape and the school and policy contexts?

- How are the ways teachers cope with or manage tensions related to the formation of teacher identities, and their effort and willingness to teach to their best?

\section{Methods}

\section{Research Framework and Design}

We adopted an interpretivist theoretical framework, in which meaning is created and negotiated by human actors through their interactions and interpretations of social contexts (Crotty, 1998; Hughes and Sharrock, 1997). Thus, understanding participants' own meaning 
making process was at the center of our inquiry. In particular, this study foregrounded the collection and analysis of participants' narratives. This entailed investigations into individual teachers' perceptions of experiences, personal and educational values prior to entering teaching and during their first two years, as they engaged in processes of constructing their professional identities. As we noted earlier, the construction of teacher identities involve ongoing and transitory processes, as they respond to and manage the interaction between personal, workplace and policy influences. Its changing nature can be best captured and understood through the participants' narratives as they organize and make sense of their experiences and ascribe meaning to them. As Hinchman and Hinchman (2001, xiv) note, "identity is that which emerges in and through narrative". In order to understand participants' "coping" and "managing" narratives over time and to capture the "socio-psycho-dynamics" of human behaviour (Rajulton, 2001,173), we employed a three-year longitudinal design.

\section{Participants}

Initially 42 pre-service teachers volunteered to be interviewed (Wave 1), and then 22 of them continued to participate in their first year teaching (Wave 2). Out of 22, six who represent various school and community contexts participated in interviews in their second year teaching (Wave 3). This study focuses upon these six participants. All six participants had completed the same teacher education program at a large Midwestern university in the U.S. As the participation of this study was on a voluntary basis, self-selection bias might be applied, and thus caution must be taken when generalizing the findings of this study to groups of different pre-service and in-service teachers. Below, table 1 provided the overall data sources, and table 2 provided the final six participants' background information. 


\section{------- Insert Table 2 Here -------}

\section{Data Collection}

After obtaining approval from the ethics review board, three waves of interviews were conducted over three years according to ethics standards and procedures. The first wave was conducted while the participants were pre-service teachers during their last semester in the teacher education program (Wave 1); the second wave was conducted towards the end of their first year teaching (Wave 2); and the last wave was conducted when they were in the middle of their second year teaching (Wave 3). Semi-structured, face-to-face interviews were conducted to explore the participants' early identities, the way they experienced transition and uncertainty, the way they coped with or managed various challenges, and the way they engaged the influences from and structures of their classrooms, schools, communities, policies, and personal lives. Each interview lasted 90 minutes to 150 minutes, and was audiorecorded and transcribed verbatim.

\section{Data Analysis}

The data were analysed using both inductive analysis (LeCompte and Preissle, 1993) and constant comparison methods (Strauss and Corbin, 1990). We compared and contrasted three waves of interviews for each participant in order to identify changes and variations across three time points. We developed coding categories inductively in order to condense extensive text into core meaning whilst reflecting the overall context. Data interpretation was also made concurrently. In order to have neither too much unwarranted personal opinion, nor too little truly insightful commentary, researcher triangulation strategy was employed, along with a member check (Coffey and Atkinson, 1996; Patton, 2002).

\section{Findings}


Findings of this study showed three distinctive patterns of coping or managing over time: (1) from coping to managing, (2) from managing to coping, and (3) continuously coping. By illustrating these differences, we aim to better understand how and why teachers' identity formation and associated sense of effectiveness varies within and between individual teachers, in relation to various personal, professional, and policy environments.

\section{From Coping to Managing}

Four participants, Jeremy, Thomas, Aiden, and Ethan, showed that they moved from coping to managing over time. However, each of them showed slightly different patterns depending on the nature of the tensions and various internal and external resources.

Jeremy, who was teaching $7^{\text {th }}$ grade English in a school located in a low-income community, experienced serious tensions in his first year, regarding instructional and classroom management approaches coupled with motivational issues stemming from students' deprived home environments. Jeremy's early identity that developed during the teacher education program included his beliefs about teaching English through deep discussions with students over literature. He wanted to teach at a high school, but only a middle school job in a low-income community, where many of students do not have proper home care and parental support, was available. His vision of instruction did not match the reality of the standards of students' performance in his $7^{\text {th }}$ grade teaching assignment. He explained the tension by highlighting his coping and how this influenced the uncertain construction of his identity.

I had no idea what a seventh grader was. I can't get them to stop talking and I learned that I can't assume knowledge anymore... And I've got another kid who is living with his grandfather in, like, a meat market, meat shop kind of thing. This kid can't 
read, but he's like, oh, I'm going to work with my grandpa. And so because of that parental figures didn't care, then you have got to find another way to motivate the kid.

So it was just a constant struggle, and I guess a crucible of everything that I am and that I've been trained to be, thrown into this position and having something burn and melted away, and certain other things reborn out of that. And I think parts of who I am or who I thought I needed to be as a teacher had to die, so I could be a better person and teacher for this role and this position.

Jeremy's initial response to the stresses of the teaching challenge was to "lose" himself in video games and to isolate himself from social interactions once he was out of the school. However, he reminded himself of his "calling" to make a difference in students' lives. He also drew his strength from the support of $7^{\text {th }}$ grade teachers, who helped him reflect on his teaching through informal discussions. School administrators also provided support by not micromanaging, but creating a safe environment where Jeremy could communicate his vulnerability and seek help.

She [school principal] is supportive mostly by letting us do our thing, instead of always micromanaging. I never feel scared or intimidated that I'm in danger from what she thinks. She observed [my classroom] and I was able to bring some concerns of scenarios and she was able to give some advice on what I could do.

Based on this in-school support and his sense of vocation, he realized that if he wanted to be effective with $7^{\text {th }}$ graders, then he needed to change his image of himself as a "serious professor" to a friendlier and more animated teacher who also pays attention to students' social and emotional needs. He, therefore, learned to manage successfully by changing his 
interpersonal interactions and teaching approaches. He began setting clearer rules and expectations for students, used various classroom activities, scaffolding those to better fit his $7^{\text {th }}$ grade students' level, and paying more attention to managing the social, emotional, and motivational issues. Consequently, in the second year, everything became "much much better." Classroom management was under control, his lessons were better, and his professional identity was more positive and stable.

Thomas, a social studies teacher at a suburban middle school, experienced 'doublebarrelled' tensions of low trust and high accountability, alongside the challenge of classroom discipline often experienced by new teachers. Thomas' initial teaching approaches included teaching social studies to young adults in a high school using the Socratic method. However, he struggled with consistency in his discipline, commenting, "I definitely felt kind of like a glorified babysitter. I've just got to make sure they don't kill each other while maybe teaching geography." This tension was aggravated when school administrators took an instrumentalist approach by enforcing the adoption of a performativity driven teacher evaluation system, which consequently contributed to Thomas' unstable identity construction and the devaluing of the relational aspects of teaching.

There's the whole evaluation system, walk throughs, observations, and stuff, it seems they're trying to do more of a 'got ya'. Here's where we can mark you off. Here's where we 'got ya'. So that was frustrating at times because I felt like I was kind of teaching while looking over my shoulder, saying uh-oh, are they going to walk in right now? And that made me kind of rigid and robotic in certain ways... The problem with that is that I lacked on some developing of relationships with kids. Because we must get through this, we've got to move on. 
Thomas also recalled the absence of support in the beginning of his first year, overemphasis on test scores, and lack of trust throughout the school year, which made him feel powerless. They gave me a room, they gave me a textbook. But aside from that, it was pretty much...go for it. There is not a lot of support given as to why it's [school-level policy] done. It was kind of like, you gotta do this for higher test scores. We've got to get kids past this point. Are they prepared to pass the test at the end of the year? We are not trusted with knowing why. It's basically here is what you should do. Don't ask questions.

Although this accountability-driven school culture was not aligned with his ideas of teaching and learning, Thomas felt unable to confront it, as "being the squeaky wheel" meant the danger of "not being renewed my contract next year."

The tensions Thomas experienced both from inside and outside of the classroom in his first year caused him to look for other jobs. In the second year, he switched to a high school position, so the context itself was radically changed. He found the students much "easier to figure out" and the administrators much more supportive. In this new context, Thomas could teach in a way similar to his initial vision of teaching Social Studies using the Socratic method and this made him feel much more fulfilled in his work and more clear and stable in his sense of professional identity.

In contrast with his previous school, he felt that the system of evaluation by the administrators in his new school was less test score-driven, but more meaningful, and he felt safe and comfortable to ask help and to rely on their support.

My principal was looking for stuff [about my teaching] that I did exceptionally well to tell me, while also saying, here's where you could improve in a couple of areas. 
Whereas last year it was kind of like, you gotta do this for higher test scores. This year, if I had a real struggle with a kid, if I talk to my principal, then they would back me up. Here I do feel like I have that security and can really work to my best, knowing that if something goes wrong, that I have that backup.

This new context helped him to manage anticipated and unanticipated challenges effectively in his daily teaching, which resulted in a positive sense of professional identity. He summarized the change of his identity, "This year I'm more a facilitator, a mentor, or a challenger, whereas last year I was more of a disciplinarian or a babysitter as a teacher. So that's kind of how my identity switched."

Aiden, a music teacher in a suburban middle school, also experienced such 'doublebarrelled' tensions between his idealistic vision for teaching and the realities of the classroom life and between his prior expectations of support from within the school and what he experienced. He saw his initial idealism about teaching and learning as being in conflict with the realities in the classroom when he realized that the students were "a little less innocent than they tell us when we were in college." Aiden was in a remote classroom at the school with many new teachers, and found it difficult to gain support from either administrators or other teachers. Besides the difficulties of setting up classroom rules and handling "disrespectful" students, he also experienced problems in building relationships with colleague teachers and school administrators. He attributed this to colleagues' lack of appreciation about the subject matter he taught, as Music is not a tested subject matter, and the school administrators" "blunt" communications.

There were a lot of teachers who questioned the importance of my subject, music, and so there were times when I felt very defensive around certain people. I almost felt like 
they [school administrators] were waiting for me to prove myself. And my principal was very blunt and he doesn't beat around the bush. I used to interpret that as rude and disrespectful.

As he acknowledged later, however, it was not only colleagues and school administrators who contributed in making the relationship difficult, but also it was Aiden's overassertiveness and lack of diplomacy. Once he had sent out a curt email to the principal that was inadvertently copied to other teachers. This incident had created "a stressful situation with some hurt feelings and some unprofessional words being said."

In his second year, Aiden improved the management of his relationships in the school. He volunteered for duty and increased his visibility around the school. He was also "smarter about communication", and tried to create opportunities to interact with other teachers regularly and to seek help from them.

And this year I'm a lot more level-headed when I speak with co-workers and my administrators, and so that just has changed my outlook. This year I've made an effort to eat in the teachers' lounge so I can talk with them and just kind of connect with them... It's more of a defeat when you don't ask for help and don't get it fixed and start doing it on your own and fail every day.

In response, he received greater support from colleagues and administrators, all of whom turned out for his students' concerts. Aiden's active agency enabled him to reach out to other teachers, better communicate with school administrators, and learn from others' perspectives. In turn, this fed into his growing sense of positive, stable professional identity.

Ethan, who was teaching English in a rural area that serves diverse socio-economic communities, perceived his teaching identity as being a "stand up comedian", who "jokes all 
throughout" and who is "very willing to go out and be silly and have fun in order to get kids excited and engaged about being at school." Although he enjoyed himself in this role, he found that it created more tensions than successes in the classroom. In his first year he identified a lack of time management skills to prepare and follow the curriculum and the challenge of meeting accountability standards.

I feel like I am under a lot of pressure to perform and I am still trying to develop, I am trying to figure out what I am doing, and then you slam this State test on top of me. I mean today I started looking at my curriculum and I realized I am not anywhere where I need to be. I am still in American Romanticism and I ought to be almost to the Modernism and the EOI's (End-Of-Instruction Test) in a week and half and I'm like what the crap this is my first time doing this.

This situation put him under a lot of pressure as he thought that "it's going to kill their grade". This consequently contributed to lower his confidence. In the first year, Ethan was mostly coping as he described, "I'm really just trying to tread water. I'm just trying to survive here."

However, he realized in his second year that he had to re-invent his identity as a teacher, otherwise he would continue to flounder. So in his second year, he figured out how to teach in ways that engaged students in learning rather than listening to his comedy routine. He went from personality-driven teaching, to an approach that focused more on activities and discussions. He learned how to better manage time so that he can stay on track for his curriculum schedule. In the process of change, he found that autonomy-supportive school environment was helpful, as it provided space for him to learn and grow through trial-anderror. Not being micromanaged seemed to help Ethan to alleviate the pressure from State 
mandated tests, all of which contributed to the development of a more positive, stable sense of identity.

One of my favourite things about this place is there is a lot of autonomy. The administration here believes that the teacher is the professional of the classroom and we are going to give you the space to do that professionally... We don't feel like we are under a microscope all day. They [school administrators] let you be yourself and let you do it your way... The fact that I'm able to be myself at a school like here, I think makes me a much better teacher.

Besides autonomy-supportive administrators, colleagues' positive emotional, social, and practical support and collegiality also seemed to help Ethan to manage day-to-day challenges.

If I needed help with a writing assignment I'd go to Mr. Curby. If I needed help with a grammar assignment and coming up with a grammar unit, I would go to Mrs. Gill because that's what she's really good at. If I need to go vent, I'm going to go down the hallway, to Mr. Oliver and we're going to talk about something. Even if I don't ask, they are really good about popping their head in to see how I am doing... a lot of people just kind of pop their head in. Hey, do you need anything? How's it going?

\section{From Managing to Coping}

Tiffany was the only participant in this study who showed negative change from managing to coping. Tiffany believed that she was born to be a teacher and, initially, her sense of confidence was high. She began teaching $2^{\text {nd }}$ graders at a school located in a middle class neighbourhood, and her confidence quickly dropped due to the challenges of implementing State and District mandated tests and the pressure within the school of 
achieving success in these. She was not sure how to align her teaching with these and her students' low test scores, which she attributed to the test difficulty, caused her to develop a negative and unstable sense of self as a teacher.

We do everything by standards... My biggest trouble is how do I know if this assignment or this thing meets the standards. It's frustrating when the State or the Federal Government or District is requiring all this stuff that isn't affecting what is going on in the classroom... So every nine weeks we're given a benchmark test. It is a district wide test. When I gave it to my kids, the reading was too hard. The math, they pulled questions from the third grade State test prep packet for beginning of second grade. My kids cry because they couldn't do the reading part, they didn't know this, and it's setting them up to fail, and I grade them and feel like I'm a horrible teacher because my kids did awful on it.

In her second year, Tiffany began experiencing additional challenges with new group of students who had more discipline problems than the group of students she taught in the first year. This made her feel much less effective in her teaching, and she became less confident and more frustrated. She began to have doubts about her career choice, as her sense of professional identity became less positive and less stable.

From the first day this year, they walked in and it was just like, all hell had broke loose. The room just feels chaotic all the time, and that drives me crazy. It's just hard. It is much harder, much harder. My teaching is more choppy because I have to be redirecting everyone. I feel like I'm not doing my job this year. I'm not that teacher I wanted to be. 
As such, Tiffany continued to cope with new classroom management challenges and on-going struggle of implementing State mandated tests in her second year. She expressed her struggles and doubtful thoughts about her career choice.

This year, I think actually going back and just surviving as if I'm first year. It's really like starting from scratch this year. There were a couple of days where I didn't eat lunch because I'd be so upset and my stomach would be hurt and I wouldn't know what to do. This year I'm asking, I really meant to be doing this? Should I be teaching second grade? Should I even be a teacher?

In this process, there was not much help or support from her colleagues or administrators. She did not feel comfortable enough to share and communicate her vulnerability with them, and the lack of trust and feelings of embarrassment hindered her from seeking necessary support and help.

I don't want people to know that I'm struggling, you know? I get nervous when I see her [the principal] now, because she has been in my room and knows what I've been going through. So I feel like I'm scared now because I know that she could get me in trouble now, so I'd rather just not say anything and not ask for help.

Ironically, at a time when she had needed most help and support, she isolated herself from colleagues and administrators, and they, in turn, did not reach out to her in a way to develop open and trusting communication either. This impacted negatively on the development of a stable, positive sense of professional identity.

\section{Continuously Coping}

Kathleen was continuously coping for both first and second year of teaching.

Kathleen had a strong desire to make differences in children's lives, and had "always known 
that teaching is what I was meant to do." However, when she began teaching in a small rural school where she had attended as a student, she experienced a tension, especially in relation to classroom management. One of the salient aspects of her early identity was to be a "fun, young, hip teacher" who is liked by students. However, her image of being that kind of teacher did not work well in her first year, when she began teaching $4^{\text {th }}$ grade reading, as the students were "walking all over" her. Especially, given the small-size of the school where "everybody knows every body like a family", the lack of professional boundaries with parents and school administrators made the student discipline issue more challenging. She commented, "Starting out teaching and not quite knowing my identity as a teacher was difficult. I tried to be too nice, and that backfired."

Kathleen had chosen to return to teach in the elementary school in a small rural town at which she had been a student, and thus most colleagues were her former teachers. Although this had given her a sense of comfort and familiarity, these pre-established relationships contributed to her feeling and being treated more like a student. This delayed her transition from student identity to teacher identity. In order to resolve her classroom management problems, she decided to be "very strict" in the second year, like the other $4^{\text {th }}$ grade teacher whose class had good test scores.

She [the other $4^{\text {th }}$ grade teacher] always had really good test scores, so that's why I decided to do the things I do, because that's what she had done and she had always had really good results. So pretty much everything I do is because she said that's what she had done, and so I decided to do that, too.

For Kathleen, "being a good teacher" meant to be like the other $4^{\text {th }}$ grade teacher who achieved good test scores. However, mimicking her made Kathleen feel like she was "mean" 
to the students, contributing to an unstable, negative sense of identity. She did not like the mean teacher persona she adopted and was not satisfied about being that kind of teacher.

During this transition process, school administrators and colleagues had not provided much support or help. Although the principal observed her classroom teaching, it was more of a formality, instead of providing constructive feedback and support. There were no formal or informal opportunities, for example, that helped Kathleen reflect about her teaching practice and sense of self as a teacher.

In the second year, she continued coping, as she tried to find her "best self" professional identity. She noted, "It's trying to keep the balance between being strict but not being a horrendous, mean person. That's kind of hard. I'm trying to backpedal and find the balance to be the kind of teacher I want to be."

\section{Discussion and Implications}

The stories of these six teachers suggest that in these early years, professional identities are likely to fluctuate. They may be either positively or negatively stable or unstable, as teachers learn/do not learn how to manage rather than continue to cope. The extent to which they are able to succeed in managing rather than coping is influenced strongly by the nature of the direct practical and emotional support they receive from colleagues and indirectly through the school culture, and likely to affect their identities as professionals and this is associated with their perceived effectiveness in the classroom. Professional identities of early career teachers may thus be regarded as "transitional."

The four participants who moved from coping and managing showed that their identities were uncertain and in transition, thus it was essential to have supportive and "safe" school environments where they could openly communicate their weaknesses, seek help, and 
try out different ways to be a teacher with constructive feedback and support (Le Maistre and Pare, 2010). As shown in Jeremy's case, even if he had a strong sense of vocation (Hansen, 1995), the sense of vocation alone was not enough to enable a stable and positive sense of professional identity to be established. Strong support from colleagues and administrators was essential for him to move from coping to managing. Similarly, when Aiden invested effort to reach out and better communicate with other teachers, it was reciprocated by them. Without such mutual effort and shared sense of commitment, he was unlikely to have been able to manage the transitional identity challenges. This echoes the importance of building a supportive, encouraging, and collaborative teacher community, which has been continuously emphasized in teacher education literature across the countries (Day and Gu, 2010; Vescio, Ross, and Adams, 2008).

Developing a school culture and environment that has shared vision, commitment, and mutual support is associated, also, with the quality of administrators. Thomas' example showed how school administrators influenced his decision to switch schools. Thomas' case especially highlights the importance of trust building, which is closely tied to the need for shared sense of agency and power (Bryk and Schneider, 2002). Ethan, who lost his strong sense of professional identity in the beginning due to the accountability demands, could manage them in the second year with the help of the autonomy supportive administrators who buffered the external demands. Although this study is conducted in the U.S. context, existing studies from other countries (e.g., Australia - Gronn, 2003; Canada - Leithwood and Jantzi, 2006; Finland - Hargreavas, Halasz, and Point, 2008; UK - Gunter, 2001; O’Brien and Forde, 2015) have consistently found that school leadership and school culture have a great impact on teacher development. 
Also, Aiden and Thomas showed how teachers exercise their individual agency differently in managing various transitions. Aiden evaluated the tensions as something he can change, thus he strived to improve the troubled relationship by exercising his agency. However, Thomas perceived the tensions with administrators as something he cannot change, and thus he rather chose to switch the context. As Lazarus (1993) noted, the way an individual teacher manages tensions in one context may not produce the same level of positive outcome in another. Although the current research shows these differences at a descriptive level, future research needs to further investigate the nature, pattern, and extent to which contextual or situational influences promote or hinder from producing positive outcomes in relation to individual teachers' inner resources, strengths, and weaknesses.

In contrast to those who moved from coping to managing, Tiffany, who moved from managing to coping, did not have necessary support from the school administrators and colleagues. Her struggle to implement mandated tests became worse due to the increasing discipline problems in the second year. This illustrates the significance of an autonomysupportive school culture, especially in the current educational climate of heightened accountability. The performativity agenda, in these cases, seemed to erode teachers' autonomy and threatens their sense of agency (Buchanan, 2015; Day, Sammons, Stobart, Kington, and Gu, 2007). Thus, the school administrators' role is critical in mediating the demand by fostering autonomy-supportive environment where teachers' power and agency are protected and distributed based on individual teachers' strengths, weaknesses, demands, and capacities.

Kathleen who was continuously coping responded to tensions reactively, instead of a thoughtful reflection and guidance. In this transition process, she could not receive much 
constructive feedback from colleague teachers or school administrators either. What is noteworthy in her case is the fact that she returned to her former school. The data set of the current study is limited in deriving any definitive conclusions about how the existing relationship with colleagues and school administrators affect beginning teachers' professional growth positively or negatively. There are no known empirical studies to investigate the impact of pre-service teachers' decision to return to their own former schools on their identity development, however, future research needs to further explore this issue with a larger sample of early career teachers.

Over a career, teachers are likely to experience many predictable and unpredictable challenges as a result of personal, professional, and policy changes. However, for early career teachers, the everyday challenges of classroom teaching and learning, which are situated within possible tensions in the school environment and accountability demands are the most immediately important. In responding to these challenges, different response patterns were identified. Some teachers were moving from coping to manging by actively overcoming or resolving the challenges, and thus moving forward to teach to their best. Others were moving from manging to coping, or continuously coping without resolving the challenges or barely surviving in the shorter term. These differences were influenced by school-level support, and also found to be associated with their efficacy, agency, and growth or decline of decisional capital.

Lastly, certain limitations of this study need to be acknowledged in relation to the future research direction. First, due to the high participants dropout rate in longitudinal studies, even if the baseline data set at Wave 1 included 42 participants, the final data set had only six teachers. Although each of these six teachers' distinctive identity development 
provides meaningful insight, the small sample size is limited in fully capturing the variations of coping and managing. Thus, the findings of this study should be interpreted with caution and should not be over-generalized. Future research needs to include a larger sample to develop comprehensive understanding about the variations of coping and managing and its relation to identity development. Second, the data set included three waves of interviews over three years. Although this study could capture the changing aspect of teacher identity to some extent, more frequent data collection at each wave would have provided more elaborated and in-depth understanding of coping and managing. Through frequent and prolonged data collection, future research needs to focus on developing refined understanding about how the situational and episode based coping responses can build up longer-term and sustainable strategies and dispositions.

A clear message from this, albeit small scale research, is that early career teachers' identities are transitional rather than fixed. In particular, this study showed the significance of support from colleagues and school administrators. Supportive school environments, especially for teachers in their early years, are key factors if they are to be willing and able to develop positive, stable, and effective teacher identities that enable them to teach effectively. 


\section{References}

Alsup, J. 2006. Teacher Identity Discourses: Negotiating Personal and Professional Spaces. Mahwah, NJ: Lawrence Erlbaum Associates.

Bandura, A. 1994. Self-efficacy. In V. S. Ramachaudran (Ed.), Encyclopedia of human behavior (Vol. 4, pp. 71-81). New York: Academic Press.

Beauchamp, C., and Thomas, L. 2009. "Understanding Teacher Identity: AnOverview of Issues in the Literature and Implications for Teacher Education." Cambridge Journal of Education, 39 (2), 175-189.

Beauchamp, C., and Thomas, L. 2011. "New Teachers' Identity Shifts at the Boundary of Teacher Education and Initial Practice." International Journal of Educational Research, $50,6-13$.

Bryk, A.S., and Schneider, B. 2002. Trust in Schools: A Core Resource for Ivmprovement. New York, NY: Russell Sage Foundation.

Buchanan, R. 2015. "Teacher Identity and Agency in an Era of Accountability.” Teachers and Teaching: Theory and Practice, 21 (6), 700-719. 
Coffey, A., and Atkinson, P. 1996. Making Sense of Qualitative Data: Complementary Research Strategies. Thousand Oaks: Sage Publications.

Cooley, C. H. 1902. Human Nature and the Social Order. New York: Scribner.

Cooper, J. M., and Alvarado, A. 2006. Preparation, Recruitment and Retention of Teachers. In IIEP education policy series No. 5. UNESCO.

Cooper, K., and Olson, M. 1996. "The Multiple 'I's of Teacher Identity.” In M. Kompf, D. Dworet, and R. Boak (Eds.), Changing research and practice (pp.78-89). London: Falmer Press.

Craig, C. 2013. "Teacher Education and the Best-Loved self." Asia-Pacific Journal of Education, 33(3), 261-272.

Crotty, M. 1998. The Foundations of Social Research: Meaning and Perspective in the Research Process. Thousand Oaks, CA: SAGE.

Danielewicz, J. 2001. Teaching Selves: Identity, Pedagogy, and Teacher Education. Albany: State University of New York Press.

Day, C., and Gu, Q. 2010. The new lives of teachers. London: Routledge.

Day, C., and Hong, J. Y. 2016. "Influences on the capacities for emotional resilience of teachers in schools serving disadvantaged urban communities: Challenges of living on the edge." Teaching and Teacher Education, 59, 115-125.

Day, C., Kington, A., Stobart, G., and Sammons, P. 2006a. “The Personal and Professional Selves of Teachers: Stable and Unstable Identities.” British Educational Research Journal, 32(4), 601.

Day, C., Sammons, P., Stobart, G., Kington, A., and Gu, Q. 2007. Teachers matter: Connecting lives, work and effectiveness. Maidenhead: Open University Press. 
Day, C., Stobart, G., Sammons, P., and Kington, A., 2006b. "Variations in the work and lives of teachers: relative and relational effectiveness." Teachers and Teaching: Theory and Practice, 12(2), 169-192.

Eteläpelto, A., Vähäsantanen, K., and Hökkä, P. 2015. "How Do Novice Teachers in Finland Perceive Their Professional Agency?” Teachers and Teaching: Theory and Practice, 21 (6), 660-680.

Fantilli, R. D. and McDougall, D. E. 2009. "A Study of Novice Teachers: Challenges and Supports in the First Years." Teaching and Teacher Education, 25, 814-825.

Farrell, T. S. C. 2003. "Learning to Teach English Language During the First Year: Personal Influences and Challenges." Teaching and Teacher Education, 19, 95-111.

Gronn, P.2003. The New Work of Educational Leaders. London: Paul Chapman.

Gunter, H. 2001. Leaders and Leadership in Education. London: Paul Chapman.

Hansen, D.T. 1995. The Call to Teach. New York: Teachers College Press.

Hargreaves, A. and Fullan, M. 2012. Professional Capital: Transforming Teaching in Every School. New York, NY: Teachers College Press.

Hargreaves, A., Halasz, G., and Pont, B. 2008. The Finnish Approach to System Leadership. In B. Pont, D. Nusche, and D. Hopkins (Eds.), Improving School Leadership: Case Studies on System Leadership (Vol. 2, pp. 69-109). Paris: OECD.

Hinchman, L., and Hinchman, S. 2001. Memory, Identity, Community. The Idea of Narrativity in the Human Sciences. New York: New York University Press.

Hong, J. Y. 2010. "Pre-service and beginning teachers' professional identity and its relation to dropping out of the profession." Teaching and Teacher Education, 26, 1530-1543.

Hughes, J. and Sharrock, W. 1997. The Philosophy of Social Research. Pearson: Essex. 
Ingersoll, R. M. 2001. “Teacher Turnover and Teacher Shortages: An Organizational Analysis.” American Educational Research Journal, 38(3), 499-534.

Johnson, S. M., and Birkeland, S. E. 2003. "Pursuing a "Sense of Success": New Teachers Explain Their Career Decisions.” American Educational Research Journal, 40(3), 581617.

Jugovic, I., Marusic, I., Ivanec, T. P., and Vidoviv, V. V. 2012. "Motivation and Personality of Preservice Teachers in Croatia." Asia-Pacific Journal of Teacher Education, 40(3), 271-287.

Kelchtermans, G. 1993. "Getting the Story, Understanding the Lives: From Career Stories to Teachers' Professional Development.” Teaching and Teacher Education, 9(5-6), 443.

Lazarus, R. 1993. “Coping Theory and Research: Past, Present, and Future.” Psychosomatic Medicine, 55, 234-247.

Lazarus, R. and Folkman, S. 1984. Stress, Appraisal, and Coping. New York: Springer.

Le Maistre, C., and Pare, A. 2010. "Whatever it Takes: How Beginning Teachers Learn to Survive." Teaching and Teacher Education 26, 559-564.

LeCompte, M. D., and Preissle, J. 1993. Ethnography and Qualitative Design in Educational Research. San Diego: Academic Press.

Leithwood, K., and Jantzi, D. 2006. “Transformational School Leadership for Large- Scale Reform: Effects on Students, Teachers, and Their Classroom Practices." School Effectiveness and School Improvement, 17(2), 201-227.

Lindqvist, P., Nordänger, U. K., and Carlsson, R. 2014. “Teacher Attrition the First Five Years - A Multifaceted Image.” Teaching and Teacher Education, 40, 94-103. 
Mockler, N. 2011. “Beyond 'What Works': Understanding Teacher Identity as a Practical and Political Tool." Teachers and Teaching: Theory and Practice, 17 (5), 517-528.

O’Brien, J., and Forde, C. 2015. "Leadership Development and Issues of Effectiveness.” In C. Chapman, D. Muijs, P. Sammons, and T. Charles (Eds.) The Routledge International Handbook of Educational Effectiveness and Improvement: Research, Policy, and Practice. Abingdon: Routledge.

Olsen, B. 2008. Teaching What They Learn, Learning What They Live. Boulder, CO: Paradigm Publishers.

Patton, M. 2002. Qualitative Research and Evaluation Methods. Thousand Oaks, CA: Sage. Pillen, M., Den Brok, P., and Beijaard, D. 2013. "Profiles and Change in Beginning Teachers' Professional Identity Tensions." Teaching and Teacher Education, 34, 86-97. Rajulton, F. 2001. “The Fundamentals of Longitudinal Research: An Overview.” Special Issues on Longitudinal Methodology, Canadian Studies in Population, 28 (2), 169-185. Rapport, D., Gill, M., and Schafer, R. 1945. Diagnostic Psychological Testing. Chicago: Year Book Publisher.

Rodgers, C. R., and Scott, K. H. 2008. "The Development of the Personal Self and Professional Identity in Learning to Teach.” In M. Cochran-Smith, S. Feiman-Nemser, D. J. McIntyre, and K. E. Demers (Eds.), Handbook of Research on Teacher Education (pp. 732-755). New York, NY: Routledge.

Ruohotie-Lyhty, M. and Moate, J. 2016. "Who and How? Preservice Teachers as Active Agents Developing Professional Identities." Teaching and Teacher Education, 40, 94 103. 
Schafer., R. 1954. Psychoanalytic Interpretation in Rorschach Testing. New York: Grune and Stratton.

Smagorinsky, P., Cook, L., Moore, C., Jackson, A., and Fry, P. 2004. “Tensions in Learning to Teach: Accommodation and the Development of a Teaching Identity." Journal of Teacher Education, 55(1), 8-24.

Stillman, J., and Anderson, L. 2015. "From Accommodation to Appropriation: Teaching, Identity, and Authorship in a Tightly Coupled Policy Context." Teachers and Teaching: Theory and Practice, 21 (6), 720-744.

Stone-Johnson, C. 2014. "Parallel Professionalism in an Era of Standardisation.” Teachers and Teaching: Theory and Practice, 20 (1), 74-91.

Strauss, A. L., and Corbin, J. 1990. Basics of Qualitative Research: Grounded Theory Procedures and Techniques. Newbury Park, CA: Sage.

Thomson, M. M., and Palermo, C. 2014. 'Preservice Teachers' Understanding of Their Professional Goals: Case Studies from Three Different Typologies.” Teaching and Teacher Education, 44, 56-68.

Thomson, M. M., Turner, J. E., and Nietfeld, J.2012. “A Typological Approach to Investigate Motivation for Teaching and Beliefs About Teaching of Preservice Teacher Candidates.” Teaching and Teacher Education, 28, 324-335.

Vähäsantanen, K. 2015. "Professional Agency in the Stream of Change: Understanding Educational Change and Teachers' Professional Identities." Teaching and Teacher Education, 47, 1 -12.

Van den Berg, R. 2002. “Teachers' Meanings Regarding Educational Practice.” Review of Educational Research, 72(4), 577-625. 
Vescio, V., Ross, D., and Adams, A. 2008. “A Review of Research on the Impact of Professional Learning Communities on Teaching Practice and Student Learning.” Teaching and Teacher Education, 24, 80-91.

Warin, J., Maddock, M., Pell, A., and Hargreaves, L. 2006. "Resolving Identity Dissonance Through Reflective and Reflexive Practice in Teaching.” Reflective Practice, 7(2), 233245.

Watson, C. 2006. "Narratives of Practice and the Construction of Identity in Teaching." Teachers and Teaching: Theory and Practice, 12(5), 509-526. 
Table 1

Overall Data Sources

\begin{tabular}{|c|c|c|c|c|c|c|c|c|}
\hline No. & Pseudonym & Gender & $\begin{array}{l}\text { Age } \\
\text { at } \\
\text { W1 }\end{array}$ & Ethnicity & $\begin{array}{l}\text { Major in } \\
\text { Teacher } \\
\text { Education }\end{array}$ & $\begin{array}{l}\text { Wave } 1 \\
\text { Particip } \\
\text { ation }\end{array}$ & $\begin{array}{l}\text { Wave } 2 \\
\text { Partici } \\
\text { pation }\end{array}$ & $\begin{array}{l}\text { Wave } 3 \\
\text { Partici } \\
\text { pation }\end{array}$ \\
\hline 1 & Thomas & $\mathrm{M}$ & 22 & Caucasian & Social Studies & $\mathrm{X}$ & $\mathrm{X}$ & $\mathrm{X}$ \\
\hline 2 & Jeremy & M & 23 & Caucasian & English & $X$ & $\mathrm{X}$ & $X$ \\
\hline 3 & Aiden & M & 21 & Hispanic & Music & $\mathrm{X}$ & $\mathrm{X}$ & $\mathrm{X}$ \\
\hline 4 & Tiffany & $\mathrm{F}$ & 23 & Caucasian & Elementary Ed. & $\mathrm{X}$ & $\mathrm{X}$ & $\mathrm{X}$ \\
\hline 5 & Ethan & $\mathrm{M}$ & 21 & Caucasian & English & $\mathrm{X}$ & $\mathrm{X}$ & $X$ \\
\hline 6 & Kathleen & $\mathrm{F}$ & 21 & Caucasian & Elementary Ed. & $\mathrm{X}$ & $\mathrm{X}$ & $X$ \\
\hline 7 & Shelby & $\mathrm{F}$ & 22 & Caucasian & Elementary Ed. & $\mathrm{X}$ & $\mathrm{X}$ & \\
\hline 8 & Krista & $\mathrm{F}$ & 22 & Caucasian & Elementary Ed. & $X$ & $\mathrm{X}$ & \\
\hline 9 & Lisa & $\mathrm{F}$ & 24 & Caucasian & Early Childhood & $\mathrm{X}$ & $X$ & \\
\hline 10 & Alexis & $\mathrm{F}$ & 23 & Caucasian & Elementary & $\mathrm{X}$ & $\mathrm{X}$ & \\
\hline 11 & Charlotte & $\mathrm{F}$ & 20 & Caucasian & Science & $\mathrm{X}$ & $\mathrm{X}$ & \\
\hline 12 & Coleen & $\mathrm{F}$ & 20 & Caucasian & English & $\mathrm{X}$ & $X$ & \\
\hline 13 & Leah & $\mathrm{F}$ & 19 & Caucasian & Elementary & $\mathrm{X}$ & $\mathrm{X}$ & \\
\hline 14 & Lily & $\mathrm{F}$ & 21 & Caucasian & Early Childhood & $\mathrm{X}$ & $\mathrm{X}$ & \\
\hline 15 & Natalie & $\mathrm{F}$ & 22 & Caucasian & Social Studies & $\mathrm{X}$ & $\mathrm{X}$ & \\
\hline 16 & Rebecca & $\mathrm{F}$ & 20 & Caucasian & Math & $\mathrm{X}$ & $X$ & \\
\hline 17 & Lindsey & $\mathrm{F}$ & 22 & Caucasian & English & $\mathrm{X}$ & $X$ & \\
\hline 18 & Shannon & $\mathrm{F}$ & 25 & Caucasian & Elementary & $X$ & $X$ & \\
\hline 19 & Kirsten & $\mathrm{F}$ & 20 & Caucasian & Elementary & $\mathrm{X}$ & $\mathrm{X}$ & \\
\hline
\end{tabular}




\begin{tabular}{|c|c|c|c|c|c|c|c|}
\hline 20 & Madison & $\mathrm{F}$ & 21 & Caucasian & Elementary & $X$ & $\mathrm{X}$ \\
\hline 21 & Brooke & $\mathrm{F}$ & 22 & Caucasian & Early Childhood & $X$ & $\mathrm{X}$ \\
\hline 22 & Lucy & $\mathrm{F}$ & 21 & Caucasian & Elementary & $X$ & $\mathrm{X}$ \\
\hline 23 & Andrew & M & 22 & Caucasian & English & $X$ & \\
\hline 24 & Jasmine & $\mathrm{F}$ & 20 & Caucasian & Math & $X$ & \\
\hline 25 & Chloe & $\mathrm{F}$ & 19 & Caucasian & Elementary & $X$ & \\
\hline 26 & Kimberly & $\mathrm{F}$ & 20 & Caucasian & Elementary & $X$ & \\
\hline 27 & Karen & $\mathrm{F}$ & 22 & Caucasian & Elementary & $X$ & \\
\hline 28 & Elizabeth & $\mathrm{F}$ & 21 & Caucasian & Science & $X$ & \\
\hline 29 & James & M & 20 & Caucasian & Elementary & $X$ & \\
\hline 30 & Corey & M & 24 & Caucasian & Elementary & $X$ & \\
\hline 31 & Ariel & $\mathrm{F}$ & 22 & Caucasian & Early Childhood & $X$ & \\
\hline 32 & Betty & $\mathrm{F}$ & 21 & Caucasian & Math & $X$ & \\
\hline 33 & Shelley & $\mathrm{F}$ & 20 & Caucasian & Early Childhood & $X$ & \\
\hline 34 & Hannah & $\mathrm{F}$ & 19 & Caucasian & Elementary & $X$ & \\
\hline 35 & Paula & $\mathrm{F}$ & 20 & Caucasian & Elementary & $X$ & \\
\hline 36 & Mary & $\mathrm{F}$ & 22 & Caucasian & Elementary & $X$ & \\
\hline 37 & Sydney & $\mathrm{F}$ & 22 & Caucasian & Math & $X$ & \\
\hline 38 & Erin & $\mathrm{F}$ & 21 & Caucasian & Social Studies & $X$ & \\
\hline 39 & Jessica & $\mathrm{F}$ & 20 & Caucasian & Music & $X$ & \\
\hline 40 & Noel & $\mathrm{F}$ & 21 & Caucasian & Elementary & $X$ & \\
\hline 41 & Brook & $\mathrm{F}$ & 21 & Caucasian & Elementary & $X$ & \\
\hline 42 & Kendra & $\mathrm{F}$ & 20 & Caucasian & Early Childhood & $X$ & \\
\hline
\end{tabular}


Table 2

Participants' Background Information

\begin{tabular}{|c|c|c|c|c|c|c|}
\hline Pseudonym & Gender & $\begin{array}{l}\text { Age } \\
\text { at } \\
\mathrm{W} 1\end{array}$ & Ethnicity & $\begin{array}{l}\text { Major in } \\
\text { Teacher } \\
\text { Education }\end{array}$ & $\begin{array}{l}\text { First Year } \\
\text { Teaching } \\
\text { Assignment }\end{array}$ & $\begin{array}{l}\text { Second Year } \\
\text { Teaching } \\
\text { Assignment }\end{array}$ \\
\hline Thomas & $\mathrm{M}$ & 22 & Caucasian & Social Studies & $7^{\text {th }}$ Geography & $\begin{array}{l}10^{\text {th }} \text { History \& } 12^{\text {th }} \\
\text { Government }\end{array}$ \\
\hline Jeremy & M & 23 & Caucasian & English & $7^{\text {th }}$ English & $7^{\text {th }}$ English \\
\hline Aiden & M & 21 & Hispanic & Music & $\begin{array}{l}6^{\text {th }}, 7^{\text {th }}, \& 8^{\text {th }} \\
\text { Choir }\end{array}$ & $6^{\text {th }}, 7^{\text {th }}, \& 8^{\text {th }}$ Choir \\
\hline Tiffany & $\mathrm{F}$ & 23 & Caucasian & Elementary Ed. & $2^{\text {nd }}$ All subject & $2^{\text {nd }}$ All subject \\
\hline Ethan & M & 21 & Caucasian & English & $\begin{array}{l}11^{\text {th }} \text { English \& } \\
\text { Coaching }\end{array}$ & $\begin{array}{l}11^{\text {th }} \text { English \& } \\
\text { Coaching }\end{array}$ \\
\hline Kathleen & $\mathrm{F}$ & 21 & Caucasian & Elementary Ed. & $\begin{array}{l}4^{\text {th }} \text { Reading \& } \\
\text { Science }\end{array}$ & $4^{\text {th }}$ Reading \\
\hline
\end{tabular}


Author Biographies

Ji Hong is an Associate Professor of Educational Psychology at the University of Oklahoma. Her research focuses on pre-service and in-service teachers' professional identity development, motivation to teach, emotions, and resilience in relation to teacher retention and teaching effectiveness. She is an Associate Editor of Teachers and Teaching: Theory and Practice, and an Editorial Board member of Contemporary Educational Psychology.

Christopher Day is a Professor of Education in the School of Education, University of Nottingham, and Professor of Educational Leadership in the School of Education and Social Work, University of Sydney. His most recent publication is Day, C. (2017) Teachers' Worlds and Work: understanding complexity, building quality. Routledge: London. During the last twenty years, he has led and continues to lead national, European, and international research and development projects in the areas of teachers' work and lives and school leadership and to collaborate in these with colleagues in Europe, USA, Brazil, Chile, China, and Australia.

Barbara Greene is a Brian E. and Sandra O'Brien Presidential Professor of Educational Psychology at the University of Oklahoma. She is the current VP of Division C of the American Educational Research Association and has been an Associate Editor of Contemporary Educational Psychology. Her primary area of research involves examining links from academic motivation to cognitive engagement and achievement. She also studies teacher learning and development. 